\title{
The external dimension of EU social security coordination
}

Citation for published version (APA):

Melin, P. (2018). The external dimension of EU social security coordination: towards a common EU approach. [Doctoral Thesis, Maastricht University]. Wolf Legal Publishers (WLP). https://doi.org/10.26481/dis.20180702pm

Document status and date:

Published: 01/01/2018

DOI:

10.26481/dis.20180702pm

Document Version:

Publisher's PDF, also known as Version of record

\section{Please check the document version of this publication:}

- A submitted manuscript is the version of the article upon submission and before peer-review. There can be important differences between the submitted version and the official published version of record.

People interested in the research are advised to contact the author for the final version of the publication, or visit the DOI to the publisher's website.

- The final author version and the galley proof are versions of the publication after peer review.

- The final published version features the final layout of the paper including the volume, issue and page numbers.

Link to publication

\footnotetext{
General rights rights.

- You may freely distribute the URL identifying the publication in the public portal. please follow below link for the End User Agreement:

www.umlib.nl/taverne-license

Take down policy

If you believe that this document breaches copyright please contact us at:

repository@maastrichtuniversity.nl

providing details and we will investigate your claim.
}

Copyright and moral rights for the publications made accessible in the public portal are retained by the authors and/or other copyright owners and it is a condition of accessing publications that users recognise and abide by the legal requirements associated with these

- Users may download and print one copy of any publication from the public portal for the purpose of private study or research.

- You may not further distribute the material or use it for any profit-making activity or commercial gain

If the publication is distributed under the terms of Article $25 \mathrm{fa}$ of the Dutch Copyright Act, indicated by the "Taverne" license above, 


\section{Summary}

With an increasing ageing population and labour shortages in several economic sectors, the EU needs and will need labour migration. When thinking about attracting labour migration, it is important to protect labour migrant's rights. Labour migrants are faced with many challenges arising from the fact that they contribute to different social security systems throughout their career. For example, they might be faced with a situation where they are not able to export their pension back to their country of origin upon retirement. Labour migrants might also be exposed to many administrative hurdles, especially if States do not communicate with each other's.

Since its beginning, the EU realized the importance of protecting social security rights of migrants in order to promote mobility. The key instruments Regulations 883/2004 and 987/2009 provide for an extensive coordination of the social security systems of the EU Member States. Next to Regulations 883/2004 and 987/2009 which cover EU citizens and their family members moving between EU Member States, Regulation 1231/2010 covers third-country nationals moving between the EU Member States. Those three regulations provide for one system of coordination where one Member State is competent for the social security situation of a person (rule on conflict of laws). The system also provides for equal treatment, export of social security benefits and a strong cooperation between the administrations of the different Member States. Finally, it makes sure that periods of insurance completed in one Member State are taken into account by another Member State. The internal dimension of EU social security coordination is a complex but uniform system.

In contrast to this, there is no uniform system of social security coordination for external mobility. In a 2012-communication, the European Commission qualified the current state of affairs as "patchy". At first glance, the situation is indeed fragmented as both the EU Member States and the EU itself have adopted legislative instruments on social security coordination with third countries. In addition, international organisations have also set standards in the field. Based on the premise that the current social security coordination is fragmented, this research aimed at:

- mapping what were the elements of the different approaches to social security coordination with third countries; 
o developing a common EU approach based on the different elements identified.

In Chapter 2, the EU approach to social security coordination with third countries was analysed. The EU adopted two types of legislative instruments: unilateral measures and EU agreements with third countries.

The unilateral measures are the EU migration Directives; i.e. the Single Permit Directive, the Long-Term Residence Directive, the Blue Card Directive, the Students and Researchers Directive, the Intra-Corporate Transfer Directive and the Seasonal Workers Directive. Those Directives provide for equal treatment with regard to social security, but they all differ in the derogations from equal treatment they allow the Member States to adopt in their implementations of the Directives. They also provide for different standards in terms of export of old-age, invalidity and survivors' benefits. Labour migrants, being high-skilled or low-skilled, all contribute to the social security system and they potentially come from the same third country. From a social security coordination perspective, the differentiation between seasonal workers, researchers or blue card holder is not justified.

In the EU agreements with third countries, there is also a lack of common approach. However, that lack of a common approach itself is not necessarily problematic. Wishing uniform rules for all third countries would be denying the specificities of their different social security systems and their actual relationship with the EU and its Member States. The EU agreements with third countries can be classified into three categories ranging from the further to the least concrete social security coordination possible with the EU.

- The first category of agreements concerns EU agreements with the EEA EFTA States and the Swiss Confederation that are considered as Member States of the EU for the purpose of social security coordination.

O The second category of EU agreements is the agreements with Turkey, Morocco, Tunisia, and Algeria that include rules on social security coordination which have been granted direct effect by the Court of Justice.

- The third and last category of EU agreements is the agreements with San Marino, Egypt, Lebanon, Jordan, Israel, the Former Yugoslav Republic of Macedonia, Albania, Montenegro, Serbia, Bosnia and Herzegovina, Russia, Moldova and Ukraine that include social security coordination provisions calling for further measures to be adopted and which were not granted direct effect by the Court. All the agreements from the third category provide guidance as to which elements of social security 
coordination should be included in future measures to be adopted by the Association Councils or the Stabilisation and Association Councils. The fact that there is differentiation between third countries is not the problem in the current approach followed by the EU with third countries. What is currently problematic however is the lack of implementation of the social security coordination provisions contained in the agreements concluded with third countries. Furthermore, so far, the EU agreements do not cover at all the position of EU citizens residing and working in third countries. In that regard, it is recommended that the EU makes it a priority to include elements of reciprocity in its agreements with third countries so as to secure the social security rights of EU citizens residing and working outside the EU.

In Chapter 3, the national approaches to social security coordination with third countries were discussed. Bilateral agreements are the traditional instruments of social security coordination. EU Member States have concluded over 350 bilateral agreements with third countries. In this research, 9 bilateral agreements were analysed in details. These were the bilateral agreements concluded by Belgium, Germany and the Netherlands with respectively India, Turkey and USA. First of all, it must be said that not all EU 28 Member States have a large network of bilateral agreements. For example, the UK does not have a bilateral agreement with India whereas it is the top destination country for Indian migrants in the EU. Secondly, the same elements of social security coordination were found in the $g$ bilateral agreements analysed. They all contain a rule on determining the law applicable, a rule on equal treatment, a rule on aggregation of periods of insurance, a rule on export of benefits and a rule on administrative cooperation. Furthermore, the further the third country is, the less social security benefits will be covered by the agreements and the longer the exemption for posted workers from paying social security contributions in the country of work will be. Finally, if one isolates the bilateral agreements concluded with a specific country, one can see very similarly worded provisions. Hence, it seems that there is a common approach followed per third country but it seems also that the common approach is coming from the third country and not from the Member States.

Chapter 4 aimed at presenting the international approach to social security coordination and reflect on their relevance for a common EU approach. The international instruments analysed were the ones adopted by the UN, the ILO and the Council of Europe. They have varying relevance for the field of social security coordination and for the future of a common EU approach. While the Member States have sometimes ratified those instruments, the EU itself cannot be a party. The UN was the first international organisation recognising the right 
to social security. It passed its competence in the field of labour migration, to its specialised agency: the ILO. ILO conventions and recommendations have become common principles generally accepted by the Member States. Furthermore, the EU regularly promotes their ratification and their compliance by the Member States. From the Council of Europe, instruments such as the European Code of Social Security, the European Convention on Social and Medical Assistance, the European Social Charter, and the ECHR were discussed. EU Member States are all parties to the ECHR and need to respect the standards set therein and through the case-law of the ECtHR. In conclusion, international instruments that have been ratified by the EU Member States constitute minimum standards that need to be respected in a common EU approach while international instruments that have been less ratified merely constitute inspirational tools.

Based on the findings of the first Chapters, it can be said that a common approach would be needed. The fragmentation between the national, European and international approaches is confusing for migrant workers and their employers who often see the EU as one entity. Within the EU approach, the disparities between the EU Directives and the lack of protection of EU citizens in the EU agreements with third countries are not justified. Furthermore, a common approach could be beneficial for the Member States in order to strengthen their negotiating position vis-à-vis third countries. However, a common approach does not necessarily mean a common approach towards all third countries. Indeed, social security coordination is based on reciprocity. The situation of a particular country and its social security system is important to take into consideration for social security coordination. Hence, a 'one size fits all' solution is not the type of common approach proposed by this research. Instead, a common EU approach coming from the Member States and the EU is proposed while allowing for differentiation between third countries. As the development of a common EU approach could be beneficial, the second aim of this research on how to develop such a common EU approach and what to include in it was achieved in Chapters 5 and 6.

Chapter 5 proposed a first policy option to the development of a common EU approach to social security coordination with third countries. It focused on the EU as being the main actor in negotiating and concluding bilateral agreements with third countries. Instead of having potentially $28 \mathrm{Member}$ States bilateral agreements with one third country, the idea was to promote one EU bilateral agreement with one third country. Two ways to conclude such an agreement were discussed. Either social security coordination is included in a broader EU agreement such as an Association Agreement. Or, the EU agree- 
ment is strictly about social security coordination, resembling what the Member States are currently having in their bilateral agreements on social security. As to the first way, the current practice of EU agreements with third countries, described in Chapter 2, is problematic as the EU agreements do not contain detailed and unconditional provisions which labour migrants can use. Hence, if a common EU approach is achieved through EU agreements, such detailed and unconditional provisions should be included. However, this raises the issue of legal competence for the EU and potential legal bases. The more detailed a social security coordination provision is envisaged, the more need there will be for adding a specific legal base on social security to reflect that element. While the legal bases of 217 TFEU, 209 TFEU, 212 TFEU or 207 TFEU permit respectively to conclude Association Agreements, Partnership and Cooperation Agreement, Strategic Partnership Agreements or Free Trade Agreements, they do not reflect the specificity of social security coordination. As to the possibility to conclude EU agreement on social security coordination instead of Member States' agreements, the lack of legal basis for the EU to act was the main problem. The traditional legal basis for social security coordination, Article 48 TFEU, cannot be used for covering the situation of third-country nationals in the EU and in a third country. The possibility of adding Article 216 TFEU or 217 TFEU to Article 48 TFEU was envisaged but rejected. The traditional legal basis for covering situations of third-country nationals, Article 79(2)(b) TFEU, is also not appropriate for covering the situation of EU citizens, either within the EU or in a third country. Article 153 TFEU which is to be used for adopting measures encouraging the cooperation between the Member States in areas such as social security and social protection of workers cannot be used for an EU agreement that would in fact replace the Member States policies in that field. Finally, the legal bases of Article 352 TFEU and enhanced cooperation were equally dismissed. It was then concluded that the first policy option of having EU agreements, strictly on social security coordination or only including some provisions on social security coordination, with third countries was not the preferred option for ensuring a common EU approach to social security coordination with third countries.

A second policy option was then envisaged in Chapter 6. The second policy option is a softer approach to the development of a common EU approach via the draft of an EU model agreement. Having in mind the experience of OECD Models in taxation and the already existing social security agreements models from the ILO and from the Council of Europe, this research proposed to develop an EU model agreements that has the following characteristics: (1) valuable for the actors who could potentially use it; (2) drafted by the relevant experts; (3) its content should be flexible and based on the best practices identified in Chapters 
2, 3 and $4 i$ (4) non-binding instrument. Although an EU model agreement would be legally feasible and would permit a common EU approach to social security coordination with third countries to be achieved, its impact is only dependent on the Member States and the EU's political wills. 


\section{Résumé}

Souffrant d'un vieillissement de sa population associé à un manque de maind'œuvre dans plusieurs secteurs d'activités, l'Union européenne a besoin et aura besoin de main-d'œuvre étrangère. Dans le cadre d'une stratégie visant à attirer cette main-d'œuvre étrangère, il est indispensable de penser à garantir les droits de ces travailleurs. Les travailleurs migrants sont exposés à des difficultés particulières du fait qu'ils contribuent souvent à plusieurs systèmes de sécurité sociale au cours de leur vie et de leurs carrières. Par exemple, les travailleurs migrants peuvent se retrouver dans une situation où ils n'ont pas le droit de retourner dans leur pays d'origine avec les pensions de l'État où ils ont travaillé.

Depuis sa création, I'Union européenne a attaché une importance toute particulière à la protection du droit à la sécurité sociale afin de promouvoir une plus grande mobilité des personnes dans I'Union. Les instruments clés de cette politique sont les règlements $883 / 2004$ et 987/2009 qui mettent en place une coordination des systèmes de sécurité sociale des États membres. Au-delà de ces règlements couvrant la situation des citoyens de l'Union et les membres de leur famille, il existe aussi le règlement 1231/2010 qui régit la situation des ressortissants des pays tiers circulant entre les États membres. Les règlements 883/2004, 987/2009 et 1231/2010 mettent en place un système de coordination complexe. Tout d'abord, ce système désigne un seul État compétent pour la sécurité sociale d'une personne. De plus, il garantit l'égalité de traitement. Ensuite, les périodes de contributions accomplies dans un État membre sont prises en compte pour le calcul de l'acquisition, le maintien ou le recouvrement d'allocations sociales dans un autre État membre. La possibilité d'exporter des allocations sociales existe. Enfin, la coopération et la communication entre États membres sont assurées. Ainsi, on peut dire que ce mécanisme de coordination des systèmes de sécurité sociale pour promouvoir la mobilité intra-UE est un mécanisme complexe mais uniforme.

Contrairement à ce mécanisme uniforme, la coordination des systèmes de sécurité sociale dans la cadre de la mobilité entre pays tiers et États membres de l'UE est composée d'une multitude d'instruments législatifs. Dans une communication de 2012, la Commission Européenne n'a pas hésité à qualifier cette approche de disparate. À première vue, c'est effectivement le cas. D'un côté, les États membres concluent des accords bilatéraux de sécurité sociale 
avec des pays tiers; de l'autre, l'UE conclut également des accords comprenant des éléments de coordination de la sécurité sociale avec des pays tiers. De plus, des organisations internationales telles que le Conseil de l'Europe ou l'Organisation Internationale du Travail ont adoptés des standards pertinents dans ce domaine. Ainsi, la recherche conduite dans cette dissertation avait deux buts :

- distinguer les différents éléments qui composent la coordination de la sécurité sociale avec les pays tiers ;

- développer une approche commune sur base des différents éléments identifiés.

Le chapitre 2 était dédié aux instruments législatifs adoptés par l'UE dans le domaine de la coordination de la sécurité sociale avec les pays tiers. Deux catégories d'instruments peuvent être distingués : des mesures unilatérales et des accords avec des pays tiers.

Les mesures unilatérales adoptées par l'UE sont les directives en matière de migration légale pour les ressortissants de pays tiers : la directive permis unique, la directive sur le statut de résident longue durée, la directive carte bleue européenne, la directive sur le séjour et la résidence à des fins de recherche ou d'études, la directive sur le transfert temporaire intragroupe et la directive sur le travail saisonnier. Celles-ci contiennent toutes une disposition assurant l'égalité de traitement par rapport à la sécurité sociale. Cependant, elles diffèrent quant aux dérogations permises lors de leur transposition par les États membres et quant à la possibilité d'exporter les indemnités d'invalidité ainsi que les pensions de vieillesse et de survie. Ces différences basées uniquement sur le statut du ressortissant de pays tiers ne se justifient pas du point de vue de la coordination de la sécurité sociale.

Les accords conclus par l'UE avec des pays tiers comprennent aussi une approche différenciée. Néanmoins, la différence est ici basée sur le pays d'origine de la personne. Une approche différente entre pays tiers peut se justifier. En effet, prêcher pour une approche commune en ce qui concerne les différents pays tiers reviendrait à nier les spécificités de leurs systèmes de sécurité sociale et leurs relations avec l'UE et les États membres. Globalement, les accords conclus par I'UE avec des pays tiers peuvent être classés en trois catégories allant de la coordination la plus complète avec l'UE à une coordination quasi-inexistante en pratique.

- La première catégorie d'accords représente la coordination la plus complète. Elle concerne les états de I'EEE/AELE (Norvège, Islande et le Liechtenstein) et la Suisse qui sont considérés comme des États membres de l'UE en ce qui concerne la coordination de la sécurité sociale. 
- La deuxième catégorie d'accords concerne les accords avec la Turquie, la Tunisie, le Maroc et l'Algérie. Ils contiennent des dispositions de coordination de la sécurité sociale. Celles-ci ont bénéficié d'un effet direct accordé par la Cour de Justice de I'UE.

- La troisième catégorie d'accords ressemble à la précédente mais les dispositions sont moins précises et n'ont pas bénéficié d'un effet direct. Il s'agit des accords avec Saint-Marin, l'Égypte, le Liban, la Jordanie, Israël, la Macédoine (ARYM), I'Albanie, le Monténégro, la Serbie, la Bosnie-Herzégovine, la Russie, la Moldavie et I'Ukraine. Ces accords prévoient que de futures mesures de coordination soient prises par les Conseils d'Association ou de Stabilisation. La réalité est que ces accords n’ont jamais été mis en pratique. Ainsi, les mesures concrètes de coordination n'ont pas été prises par les Conseils respectifs.

De plus, les accords conclus par l'UE avec des pays tiers couvrent exclusivement les ressortissants des pays tiers et pas les citoyens européens. Face à ces conclusions, il est important que les mesures de coordination manquantes soient adoptées et que I'UE se préoccupe également de la situation de ses citoyens résidant et travaillant en dehors de son territoire.

Le chapitre 3 était consacré à l'approche suivie par les États membres. Bien qu'il existe plus de 350 accords bilatéraux de sécurité sociale entre les États membres et des pays tiers, cette recherche s'est focalisée sur 9 accords entre la Belgique, I'Allemagne et les Pays-Bas, et I'Inde, la Turquie et les ÉtatsUnis. Tout d'abord, ces accords sont très similaires en termes de structure et de principes de coordination. Néanmoins, le diable est dans les détails et on peut clairement observer une différenciation par pays tiers. Ainsi, lorsque le pays tiers est éloigné géographiquement de I'UE, I'accord aura tendance à ne couvrir que les indemnités d'invalidité, les pensions de vieillesse et les pensions de survie. Aussi, plus loin est le pays, plus longtemps il sera possible pour les travailleurs détachés de rester sous le régime de sécurité sociale de leur pays d'origine. Ces observations permettent de conclure qu'il existe, au niveau national, une approche commune par pays tiers. Cependant, il semblerait qu'elle vienne plutôt des pays tiers eux-mêmes que des États membres de l'UE qui, eux, n'agiraient pas de concert. De plus, bien que le choix de cette recherche se soit porté sur des États qui ont conclu des accords, il faut dire que ce n'est pas le cas des vingt-huit États membres de I'UE. Un des exemples les plus frappants est I'absence d'accord entre le Royaume-Uni et l'Inde, alors que le Royaume-Uni est le pays européen accueillant le plus de travailleurs indiens.

Les instruments adoptés par des organisations internationales et leur pertinence pour le développement d'une approche commune ont été présentés 
au chapitre 4. Les organisations internationales qui sont importantes pour le sujet de cette recherche sont les Nations Unies, I'Organisation Internationale du Travail (OIT) et le Conseil de l’Europe. Bien que les Nations Unies aient été la première organisation internationale à proclamer le droit à la sécurité sociale, son impact dans le domaine est aujourd'hui réduit. La compétence en matière de migration des travailleurs a maintenant été reprise par son agence spécialisée, I'OIT. Les conventions et recommandations de I'OIT sont considérées comme énonçant des principes communs et reconnus des États membres. De plus, I'UE demande régulièrement aux États membres de ratifier et de respecter les conventions de I'OIT. Les instruments du Conseil de l'Europe tels que le Code européen de la sécurité sociale, la Convention européenne d'assistance sociale et médicale, la Charte sociale européenne ainsi que la Convention européenne des Droits de l'Homme (CEDH) ont également été abordés. Concernant la CEDH, son impact est sans doute le plus visible du fait que tous les États membres sont États parties à la CEDH et doivent donc respecter les dispositions ainsi que leur interprétation par la Cour européenne des Droits de l'Homme. Il faut noter que les États membres n'ont pas toujours ratifié les instruments adoptés par les Nations Unies, I'OIT ou le Conseil de l'Europe, et que I'UE elle-même ne peut pas être partie à ces instruments. Leur impact sur la coordination de la sécurité sociale est donc de degré différent selon I'organisation. Ainsi, les instruments des organisations internationales qui ont été ratifiés par les États membres constituent des principes qui formeront la base d'une approche commune tandis que les autres instruments serviront de sources d'inspiration.

Sur base des conclusions des premiers chapitres, on peut dire qu'une approche commune est nécessaire. Les disparités entre les approches des États membres, de l'UE et des organisations internationales entrainent une confusion pour les travailleurs migrants et leurs employeurs qui considèrent souvent I'UE comme une seule entité. Au niveau européen, les différents standards de protection offerts par les directives ainsi que le manque de couverture des citoyens européens par les accords conclus avec les pays tiers sont problématiques. De plus, une approche commune pourrait s'avérer bénéfique pour les États membres qui, unis, se retrouveraient alors dans une position de négociation plus confortable face aux pays tiers. Néanmoins, par approche commune, cette recherche n'entend pas de proposer une solution unique à tous les pays tiers. Au contraire, la coordination des systèmes de sécurité sociale reposant sur le principe de réciprocité, il est important de garder une approche individualisée par pays tiers. On entend donc par approche commune une même approche de la part de l'Union européenne et de ses États membres vis-à-vis des pays 
tiers. Deux propositions d'approche européenne commune ont été apportées aux chapitres 5 et 6 .

Au chapitre 5 , une approche européenne commune a été proposée via la conclusion d'accords européens avec des pays tiers. Sous cette première proposition, I'UE est le principal acteur dans la négociation et la conclusion d'accords avec des pays tiers. Ainsi, au lieu d'avoir potentiellement vingt-huit accords conclus par les États membres, l'idée est d'avoir un seul accord européen. Cette idée peut être exploitée de deux manières : soit l'accord européen est un accord global qui comprend notamment des dispositions de sécurité sociale, soit cet accord porte exclusivement sur la coordination des systèmes de sécurité sociale. La pratique d'accord global comprenant des dispositions de sécurité sociale, tel qu'un accord d'association par exemple, existe déjà. Le chapitre 2 a permis de mettre en lumière les carences d'une telle pratique, la principale étant le manque de mise en œuvre d'une réelle coordination des systèmes de sécurité sociale de la part des Conseils d'association. Ainsi, si une telle pratique est utilisée pour asseoir une approche européenne commune, il est primordial d'inclure dans l'accord des dispositions claires et précises qui ne demanderaient pas une mise en œuvre a posteriori. Ceci étant dit, l'inclusion de dispositions détaillées nécessiterait une base juridique reflétant l'importance de ces dispositions. Les bases juridiques pour les accords de l'UE avec des pays tiers sont généralement l'article 217 TFUE pour un accord d'association, l'article 209 TFUE pour un accord de développement, l'article 212 TFUE pour un accord d'investissement et l'article 207 TFUE pour un accord de libre-échange. Ces bases juridiques ne reflètent pas la dimension de la coordination des systèmes de sécurité sociale et ne seraient donc pas suffisantes. En ce qui concerne la conclusion d'un accord portant exclusivement sur la coordination des systèmes de sécurité sociale, le principal problème est également le manque de base juridique qui permettrait à l'UE de conclure un tel accord. L'article 48 TFUE, qui est la base juridique usuelle en ce qui concerne la coordination de la sécurité sociale, n'est pas appropriée pour couvrir la situation de ressortissants de pays tiers dans ou en dehors de I'UE. La possibilité d'y ajouter l'article 216 ou l'article 217 TFUE a été envisagée mais écartée. Quant à la base juridique usuelle en ce qui concerne la situation des ressortissants des pays tiers, l'article 79(2)(b) TFUE, elle ne peut pas viser la situation de citoyens européens. L'article 153 TFUE portant sur les matières de politique sociale européenne permet de coordonner les pratiques des États membres. Ainsi, l'article 153 TFUE ne semble pas approprié dans le cadre d'un accord conclu par I'UE qui viendrait remplacer et non pas coordonner les pratiques des États membres. Finalement, les bases juridiques que sont l'article 352 TFUE et la coopération renforcée ont également été rejetées. Ainsi, la 
première option qui était de conclure des accords de I'UE avec des pays tiers n'est pas l'option qui semble la plus adéquate juridiquement ou politiquement afin de promouvoir une approche européenne commune.

À la place, une deuxième option a été proposée dans le chapitre 6 . Cette deuxième option envisage le développement $d^{\prime} u n e$ approche européenne commune via un modèle d'accord de sécurité sociale. Ce type de modèle existe déjà dans d'autres domaines tels que celui des conventions fiscales avec les modèles de l'OCDE ou bien dans le domaine de la sécurité sociale avec les modèles de I'OIT ou du Conseil de l'Europe. Ainsi, en s'inspirant des pratiques entourant ces modèles, cette recherche propose que le modèle européen d'accord de sécurité sociale comporte certaines caractéristiques. Premièrement, le modèle d'accord doit être utile et considéré comme une plus-value pour les administrations qui l'utiliseront. Deuxièmement, le modèle doit être rédigé par des experts dans le domaine et préférablement par les administrations qui l'utiliseront par après. Troisièmement, le contenu du modèle doit être adaptable aux différents systèmes de sécurité sociale des pays tiers et doit se baser sur les meilleures pratiques identifiées aux chapitres 2, 3 et 4. Quatrièmement et dernièrement, I'utilisation du modèle doit être recommandée mais pas obligatoire. Cette deuxième option se concentre sur les États membres en tant que leaders et en tant que décideurs d'une approche européenne commune. L'UE est également impliquée via la Commission européenne qui agit en tant que secrétariat de la commission administrative de la coordination de la sécurité sociale mise en place dans le cadre du règlement 883/2004. Ainsi, le cadre institutionnel et juridique étant déjà existant à travers cette commission administrative, la réelle réussite d'une approche européenne commune à travers I'utilisation de ce modèle d'accord dépendra essentiellement de la volonté politique des États membres et de I’UE. 